\title{
EJA, ECONOMIA SOLIDÁRIA E TRABALHO: PENSAR NO FUTURO É VIVENCIAR O PRESENTE?
}

\author{
Hellyegenes de Oliveira, Universidade Federal de Campina Grande (UFCG), \\ hellyegenes@hotmail.com \\ Lucimeiry Batista da Silva, Universidade Federal da Paraíba (UFPB), \\ meiry11@gmail.com \\ Vorster Queiroga Alves, Universidade Federal de Campina Grande (UFCG) \\ vorster.queiroga@gmail.com
}

PALAVRAS-CHAVE: EJA. Trabalho. Economia Solidária.

\section{INTRODUÇÃO}

Tendo o processo da economia solidária como um fator primordial nos processos que dizem respeito às relações interpessoais e a construção dos condicionamentos humanos e tendenciosos nas relações de trabalho na Educação de Jovens e Adultos (EJA), este trabalho surge na perspectiva idealizadora e construtiva em torno das pesquisas, reflexões e práticas educativas, desenvolvidas de uma intencionalidade diversa da educação: pautada na participação popular, na construção de outras relações econômicas e sociais, visando como intenção maior (re) conhecer relações possíveis e admissíveis, entre a educação popular no empreendimento social e na escola pública, a partir da percepção, mobilização e vivência dos trabalhadores jovens e adultos, oriundos das escolas de assentamentos agrícolas.

O mesmo objetiva Estudar as práticas da economia solidária e cooperativismo na percepção dos alunos da EJA na Escola M.E.I.E.F, “João Alexandre de Oliveira localidade do Assentamento Juazeiro, no Município de Marizópolis- PB.

\section{METODOLOGIA}

A pesquisa teve como foco os 80 alunos da Escola Municipal de Ensino Infantil e Fundamental "João Alexandre de Oliveira", localizada na comunidade do Assentamento Juazeiro, Município de Marizópolis - PB. Os alunos foram ouvidos, sendo aplicado um 
questionário, com questões que entornam o tema da Economia Solidária e suas relações com a referida comunidade, pois todos os alunos apresentavam perspectivas e diversificações em torno do conceito e condicionamento do trabalho na sociedade em que eles estavam inseridos.

$\mathrm{Na}$ construção dos conceitos para esta pesquisa serviram como presentes instrumentos o método descritivo, indagando uma exposição dos dados colhidos nos questionários e assim interpretá-los para que se constitua e sane as idealizações levantadas pela problemática em questão.

Os objetivos que se elencam no decorrer do estudo idealizam a prática do trabalho agregados a economia solidária como um meio inovador e consequentemente que o mesmo possa ser atribulado a novas perspectivas e condicionamentos em torno do futuro destes indivíduos, que hoje integram a modalidade da educação de jovens e adultos.

\section{RESULTADOS}

A comunidade do Assentamento Juazeiro é uma comunidade praticamente constituída por agricultores e pessoas que vivem de acuidades e assistencialismos financeiros principalmente as de incentivo público, indivíduos estes que em sua maioria não apresentam perspectivas de desenvolvimento e beneficiamento principalmente acerca do processo trabalhista que envolva a economia solidária.

Em meio as pesquisas e documentações elencadas pelos levantamentos feitos constatou-se que $40 \%$ dos entrevsitados não possuem nenhum tipo de renda segura, advinda de uma especie de vínculo empregaticio, dentre os pesquisados $97 \%$ recebem algum auxilio governamental, tais como o Programa Bolsa Famila. Verificou-se ainda que $90 \%$ não possuem outra fonte de renda a não ser esta advinda dos programas assistencialistas.

Logo, todos os dias encontramos nas classes da EJA trabalhadores sufocados e insatisfeitos com este modelo de economia predominante. Indivíduos que na maioria dos casos largaram o ensino regular na infância para trabalhar, buscando assim sobreviver.

(...) quando estamos lidando com o saber e o aprender, o que se vive é só um cuidadoso e lento trabalho de lidar com momentos inesperados da experiência de vida de cada pessoa educanda. De olhar nos olhos uma gente que não raro precisou esperar não mais da metade da vida para ser aceita em um banco de escola (BRANDÃO, 2002, p.43). 
Constatou-se por meio destes condicionamentos que a renda da maioria dos indivíduos desta comunidade, em especifico os alunos da EJA, basicamente não apresentam uma fonte de renda satisfatória, mas sendo uma renda variável complementar.

Nas relações do trabalho no cotidiano dos alunos da EJA, 50\% idealiza que a escola deve incentivar a formação para o mercado de trabalho, $10 \%$ gostariam de ter um novo emprego, $30 \%$ acreditam que o trabalho liberta e edifica o homem nas suas diversas capacidades sociais e intelectuais e $10 \%$ já ouviram falar sobre a prática da economia solidária.

Acreditando na educação como uma possibilidade de transformar de alguma forma a realidade social, principalmente no que se refere à realidade do aluno-trabalhador, faz-se necessário trabalhar alguns princípios como a fraternidade, cooperação, solidariedade, colaboração, autogestão e outros presentes na Economia Solidária.

A Economia Solidária é um ato pedagógico em si mesmo, na medida em que se propõe uma nova pratica social e um entendimento novo dessa pratica. A única maneira de se aprender a construir a Economia Solidária (SINGER, 2005, p. 19).

Diante dos resultados elencou-se que existe uma prática de desenvolvimento em torno da ideologia dos alunos, mas infelizmente muito pouco destes conceitos são colocadas em prática. Existe uma vontade de buscar o novo e consequentemente de instruir novas práticas em torno da vida destes indivíduos, por meio de maneiras práticas e eficientes, sendo que a prática da economia solidária apresenta-se como uma maneira singular em questionar e indagar estes procedimentos de transformação.

\section{CONSIDERAÇÕES FINAIS}

Inserir na proposta curricular e no cotidiano dos docentes e discentes os princípios da Economia Solidária envolve inovar também as práticas pedagógicas e descobrir que ser educador é estar disposto a mudar em todas as necessidades que surgirem ao longo do processo educacional. Propor aos alunos da Educação de Jovens e Adultos uma prática pedagógica, que envolvesse sair da zona de conforto e praticar, a todo o momento, desafios é 
preciso confiança e credibilidade no que é proposto. O desafio é desenvolver atividades que sistematizem os princípios da Economia Solidária.

Em diversos momentos durante o conceito do estudo houveram relatos das insatisfações e frustrações em relação as funções exercidas e a baixa remuneração. Este projeto proporcionou a percepção do quanto os alunos revelaram nas discussões suas identidades oprimidas e massacradas pela crueldade do sistema, que os tornam apenas mão de obra barata, seres alienados e passivos de toda e qualquer situação apresentadas pelos "grandes senhores" que detêm o capital.

Compete ao educador incentivar esses aspectos em sala de aula e contribuir para a formação de um indivíduo responsável, independente e cidadão. O educador da EJA tem um grande desafio a ser enfrentado que é estimular o jovem para a aprendizagem com metodologias inovadoras e difundidas ao seu cotidiano, mas estas práticas são desestruturadas pelas atuais crises sociais pelas quais os educadores se confrontam no seu dia a dia, refletindo em uma educação falha e alunos indispostos ao processo da aprendizagem. Por fato é necessário elencar que a educação está diretamente ligada com o trabalho por meio destes condicionamentos a sociedade evolui e consequentemente abandona situações e crises que permeiam as suas vidas.

\section{REFERÊNCIAS}

BRANDÃO, Carlos Rodrigues. A educação popular na escola cidadã. Petrópolis: Vozes, 2002

CIAMPA, Antônio da C. A estória do Severino e a historia da Severina. São Paulo: Brasiliense, 1994.

FREIRE, Paulo. A educação como prática da liberdade. Rio de Janeiro: paz e Terra, 2002.•

FREIRE, Paulo. Pedagogia do Oprimido, Rio de Janeiro, Paz e terra, 2005.

GHEDIN, Evandro \& Borges, Heloisa da Silva. Educação no Campo - A epistemologia de um horizonte de formação. Manaus: UEA edições, 2007.

GIL, A. C. Métodos e técnicas de pesquisa social. 5. ed. São Paulo: Atlas, 1999.

GONZÁLEZ REY, F. L. Pesquisa qualitativa em psicologia: caminhos e desafios. Trad. Marcel Aristides Ferrada Silva. São Paulo: Pioneira Thomson Learning, 2002. 
MIRANDA, Sonia Guariza et al. GHEDINI, Cecília Maria. JANATA, Natacha Eugênia. Educação do Campo em movimento: teoria e prática cotidiana: volume II Curitiba: Ed. UFPR, 2010.

PINTO, G. Augusto. A Organização do Trabalho no século 20, Editora Expressão Popular, 2007

SENAES, SPPE, DEC, 2006. 47 p. I Oficina Nacional de Formação Educação e Economia Solidária, documento final.

SINGER, P. Introdução à Economia Solidária. Editora Fundação Perseu Abramo, 2002.

SINGER, Paul, Migrações internas: considerações teóricas sobre o seu estudo, in Moura Hélio, op. cit. TAUILE, José Ricardo, Rodrigues Huberlan, Economia Solidária e Autogestão no Brasil, Síntese de uma Pesquisa, 2005. 